\title{
The Liberalization of Electricity Market in the System of Measures for Improving Industrial Enterprisers Competitiveness: The Case of Russia
}

Melnik A.N.

Kazan Federal University, Kazan, 420008, Russia

Mustafina O.N.

Kazan Federal University, Kazan, 420008, Russia

Email address: onmustafina@gmail.com

\section{Doi:10.5901/mjss.2014.v5n18p293}

\begin{abstract}
Abstract. The article describes main problems that constrain domestic enterprises competitiveness in conditions of world economy globalization and Russia's accession to the World Trade Organization. One of the most important problems is a high level of production energy intensity. Our study focuses on the notion that liberalization of electricity market has a great impact on enterprises performance and is emphasized as another factor that influence on the enterprise competitiveness. The impact of electricity market liberalization on the enterprisers, which belong to various branches of industry, is defined. The place of the liberalization of electricity and power market in the system of measures aimed to improve the enterprises competitiveness is specified.
\end{abstract}

Keywords: Russian economy, liberalization of electricity and power market, industrial enterprises, competitiveness, energy efficiency

\section{Introduction}

Russia's entry into the World Trade Organization (WTO), supported by the major world powers, is accompanied by simplification of access to the domestic market for foreign producers and, consequently, increased competition. This determines the need to develop a whole range of measures aimed to improve the competitiveness of Russian enterprises. Among many issues of particular concern is high degree of depreciation of fixed assets, technical and technological backwardness in a number of industries, as well as the high energy intensity of production, that greatly limits the competitiveness of Russian producers. In these conditions keeping the competitive position of Russian companies on the present level becomes impossible without solving the whole complex of problems aimed at radically energy efficiency of production improving [1].

\section{Method}

In the frame of the research the systemic impact of electricity market liberalization on the enterprises, which belong to various sectors of Russian economy, was analyzed. In order to identify the role of electricity market liberalization in the system of measures aimed to improve industrial enterprises competitiveness, it was considered as a factor affecting the efficiency of the energy industries and related industries enterprisers, as well as industrial enterprises. In order to identify the logical relationship between transformations in energy sector and industrial enterprises competitiveness, a special study was conducted. It aimed, firstly, to establish the reasons of high energy consumption, as one of the factors limits Russian enterprises competitiveness; secondly, to identify systemic impact of energy sector efficiency on the enterprises, which belong to various sectors of Russian economy, competitiveness; thirdly, to determine the impact of electricity market liberalization on industrial enterprises competitiveness. 


\section{Results}

\subsection{Causes of Russian industry high energy intensity}

According to various estimates, the level of energy consumption per unit of gross domestic product (GDP) in Russia is still two - three times higher than in developed countries (Table 1). According to some sources [2] in 2013 Russian economy is still among ten most energy-intensive economies in the world.

Table 1: Energy intensity of GDP in different countries in 2013 (koe/\$) [3]

\begin{tabular}{|c|c|c|}
\hline 1 & Colombia & 0,077 \\
\hline 2 & United Kingdom & 0,091 \\
\hline 3 & Spain & 0,096 \\
\hline 4 & Italy & 0,099 \\
\hline 5 & Portugal & 0,103 \\
\hline 6 & Turkey & 0,106 \\
\hline 7 & Japan & 0,112 \\
\hline 8 & Germany & 0,113 \\
\hline$\ldots$ & & 0,168 \\
\hline 20 & USA & \\
\hline$\ldots$ & & 0,331 \\
\hline 41 & Russia & \\
\hline
\end{tabular}

We could distinguish three main reasons of present situation. The first is that the level of energy consumption is highly depends on climate. Low temperatures and its significant fluctuations is particular for the most part of the territory of Russia [4]. Thus, in northern parts of Russia additional energy costs associated with heating could be higher than the European average up to $30 \%$

The second is that level of energy consumption depends on production structure. The share of industrial production prevails in the production structure of Russia's GDP. It accounts for about 35\%. The situation is different in developed countries, which try to develop less energy-intensive branches of industry. For example, the share of industrial production in GDP was 24\% in U.S.A. in 2013, while in Japan - 22\%. However, the share of services in these countries is almost $75 \%$. At the same time power consumption in this area is considerably lower than in the industrial sector $[5,6]$.

The third is that the reduction of energy intensity of Russia's economy constrained by technological backwardness of various industries. To date, many industrial enterprises in Russia continue to use outdated equipment. According to various estimates, currently $15 \%$ of fixed assets which operate in industry are fully depreciated. In some industries, depreciation of fixed assets reaches even 50\% [7]. Of particular concern is the state of the energy sector. According to some sources, more than $90 \%$ of power plants, $70 \%$ of boilers and process equipment of electrical networks and $66 \%$ of heat networks were built prior to 1990 [8]. Physically and morally outdated equipment on the Russian energy system facilities entails, firstly, reducing its efficiency at all stages of the production process; secondly, the increase in energy losses; thirdly, reducing the reliability of the energy system and, as a consequence, increase the risk to consumers of energy products.

Elimination of reasons mentioned above could be considered as a strategic task, which aimed to reduce Russian economy energy intensity.

\subsection{The influence of the energy sector efficiency on industrial enterprisers' competitiveness}

Energy sector efficiency is the basis of sustainable development of the economy and its competitiveness [9]. The energy sector influence on industrial enterprisers operation is primarily defined through the price of energy products, which directly affects the cost of production, as well as the reliability of consumers' power supply reliability with the necessary energy, which breakdowns could lead to significant economic losses. These parameters also depend on a number of factors (Fig. 1). 


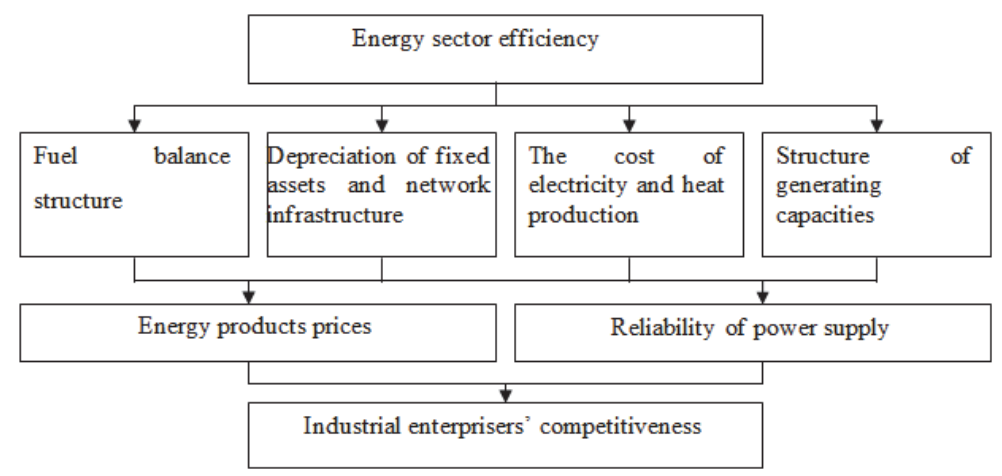

Figure 1. The influence of energy sector efficiency on industrial enterprisers' competitiveness

\subsection{The influence of electricity market liberalization on enterprises which belong to various branches of economy}

The energy sector reform took a special place in the state support system of the producers. The development of energy sector market infrastructure, based on the implementation of the competitive pricing mechanisms and formation of the institutions of an open energy trading, is one of necessary conditions for successful energy efficiency problem solving. A competitive market environment formation was identified as one of the main priorities for energy sector development, and already finished electricity market liberalization was seen as an essential condition necessary to control the growth of tariffs for energy products.

\subsection{The influence of electricity market liberalization on enterprises which belong to energy sector and related branches of economy}

Transformations held in Russia primarily affected the energy sector enterprisers. Firstly, the use of competitive pricing mechanism for energy products became an important factor, influencing the cost reduction for many of its producers [11]. Since the beginning of 2011 all the electrical energy in the country began to be sold at competitive prices. The need to provide a competitive price in the selection of bids on the market requires from power manufacturers to search out new opportunities to improve the efficiency of their own activities.

Secondly, the privatization of large share of the generating, distribution and power services companies allowed to attract significant amounts of investment needed for renovation of fixed assets and for the introduction of modern technologies in the working of power companies. Reliable modern technological basis of energy system operating is a fundamental requirement for sustainable development not only the energy sector but also the Russian economy.

Thirdly, the development of competitive relations in the power allowed to optimize the operation of the Unified Energy System of Russia, which provides a lower total cost of production, transmission and distribution of energy as compared to the pre-existing tariff system. This is achieved through the use of the mechanism of price bids from power suppliers, which assume loading, above all, the most effective generating capacities.

Fourthly, the modern system of management of the power complex of the country calls for greater state control over the infrastructure segment of the power industry, and it also calls for the modernization of the accounting and control system for power flows. Accurate accounting for the power production and consumption increases power system management ensures the reliability of power supply and promotes the growth of the investment attractiveness of the industry.

It should be noted, that the past transformation contributed to the positive results, not only in the power industry, but also in many other industries and fields, including energy equipment production, construction, metallurgy, gas industry, etc [10]. This is largely due to the fact that the introduction of new fixed assets in the power sector became a powerful incentive to increase orders for modern power equipment, construction, engineering and other services. 


\subsection{The influence of electricity market liberalization on industrial consumers of energy products}

Liberalization of the electricity market caused significant changes in the functioning of energy products consumers. The electricity market has gradually shifted into a qualitatively new state, the main feature of which is the development of competition in it. In addition to market generating and distribution companies, also the end users of power products become active subjects of market relations, including, most notably, the industrial enterprises. Thus, carried out liberalization of the electricity market in Russia can be viewed as the emergence of a new factor, which has significant impact on industrial enterprisers competitiveness.

The process of electricity market liberalization can be viewed from different perspectives. First, offered by the electricity market liberalization strategy forming opportunities and behavioral tactics on it, including, above all, the possibility of choosing a power supplier, permit to attribute the market to the factors of the microenvironment $[12,13]$. In this context, the power market can be seen as an integral infrastructure element in the functioning of the industrial enterprises. For these purposes the work of wholesale and retail electricity markets and power exchange is organized, as well as the necessary infrastructure, which provides functioning of these markets [14]. Guaranteeing suppliers were determined in every Russian region, which carry out the functions of distribution companies and pledged to serve any customer. New organizations, involved in designing, installation and maintenance of commercial electricity and power accounting systems, required both producers and consumers of energy products, appear. All this forms the basis of reliable uninterrupted supply of electric energy and power to consumers, which is an essential condition of any enterprise operation [15].

Undertaken liberalization can be seen from the other side At the signing of the free contracts the enterprise directly interacts with the power supplier. And the companies already present on the wholesale power market, have received an opportunity to choose, firstly, the segment of the market for power purchasing, including the day-ahead market, the market of free bilateral contracts, power exchange; secondly, a supplier of power energy and thirdly, the type of contract for power supply and its conditions. Enterprises functioning in the retail power market, have received the choice of the marketing company and the terms of cooperation with it. In other words, the liberalization of the power market allowed to engage the companies in the process of actively choosing their most preferred power supply alternatives for their own production and economic activities.

Secondly, the successful implementation of the above allows to consider a system of power supply as a source of competitive advantage of the enterprise. Exactly as a result of the reforms, it became possible to realize various energy strategies [16]. In new conditions energy strategy could cover several targets, including providing the industrial and economic activities with the necessary power resources at competitive prices, insuring from possible fluctuations in the wholesale and retail electricity market, as well as obtaining additional income through the commission from various operations in the wholesale electricity market and energy exchange.

Thirdly, the liberalization of the power market can also be seen as a risk factor for all its participants. The reason for that lays in the fact, that the competition, as a rule, always increases the uncertainty of behavior of the environment. For businesses, this is expressed primarily in the unstable dynamics of the power prices and in the complexity of its prediction. It should also be taken into account, that there are risks arising from the sale of excess volume of power consumption, obtained through a bilateral agreement at the market pricing and for a day ahead, which may be lower than the agreement price. The same applies to the possible deviations during purchase or sale from the planned power consumption in the balancing market.

\subsection{The liberalization of electricity market in the system of measures for improving Russian enterprises competitiveness}

Taking into account all mentioned above, we could make a conclusion that the electricity market liberalization is associated with significant changes in industrial enterprisers operating conditions. It should be noted, that companies must take into consideration this changes wile designing their competitive strategies, cause energy costs directly affect the final product cost and, consequently, its competitiveness. Particular attention should be paid to the selection of suppliers of electricity, optimal planning of energy consumption, the formation of economically justified tariff plans and a number of others.

All this indicates that the electricity market liberalization take a special place in system of measures, aimed to improve Russian enterprisers competitiveness. The development of competition in the electricity market, as a necessary condition for energy efficiency improving of both on enterprisers belong to energy sector and other branches of economy, forms the basis for Russian economy sustainable development and for improving its competitiveness (Fig. 2.). 


\section{Conclusion}

The study found that one of the most important issues, significantly restricts the Russian industry competitiveness is the high level of energy consumption. The study revealed a strong correlation between the energy sector functioning efficiency and the industrial enterprises competitiveness, which is determined by the reliability of consumers' power supply and the price level set on energy products. Based on this study the position that liberalization of electricity market is one of the most important areas in the system of measures for reducing the Russian economy's energy intensity was justified.

\section{Acknowledgments}

This work was funded by the subsidy allocated to Kazan Federal University for the state assignment in the sphere of scientific activities

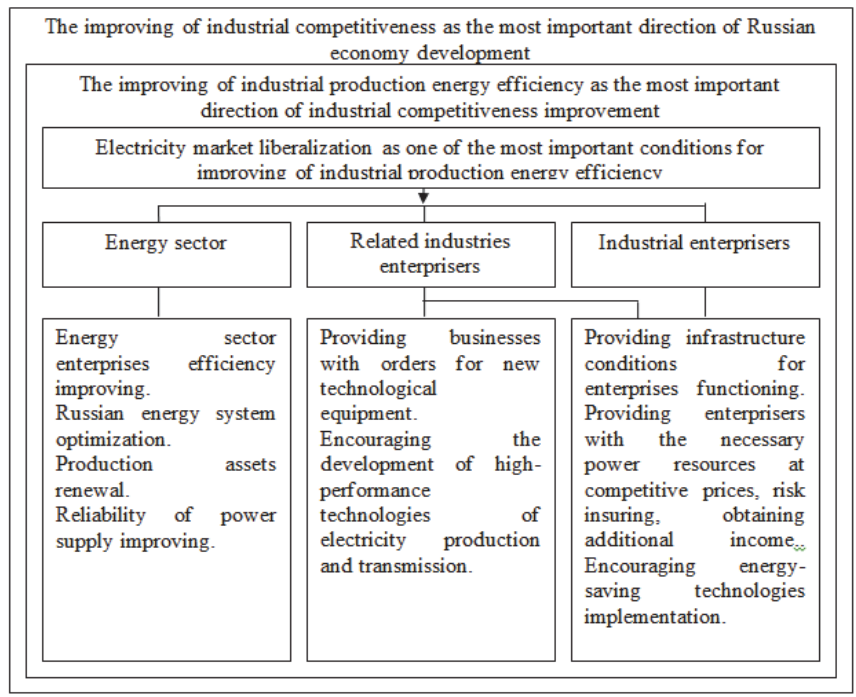

Figure 2. The liberalization of electricity market in the system of measures for improving Russian enterprises competitiveness

\section{References}

Melnik, A.N., L.V. Lukishina and R.R. Khabibrakhmanov Methodological Foundations of the Formation of the Energy Strategy of an Enterprise // World Applied Sciences Journal, 23 (8), 2013, pp. 1085-1089.

Federal State Statistic Service of the Russian Federation: www.gks.ru

Energy data intelligence: $h$ ttp://www.enerdata.rul

Fakhrutdinova, E., Kirshin,I., Kolesnikova, J., Salyakhov, E. The influence of cross-country technological transfer on economic profit formation // Middle East Journal of Scientific Research. Volume 17, Issue 12, 2013, pp. 1632-1634.

Melnik, A.N., Sadriev A.R.. Challenges and Opportunities for the Energy Clusters Formation // World Applied Sciences Journal, 27, 2013, pp.194-197.

Engoian, A. Industrial and institutional restructuring of the Russian electricity sector: Status and issues // Energy Policy (34), 2006. pp. 3233-3244.

Russian Energy strategy to the period up to 2030 year: http://minenergo.gov.ru /aboutminen/energostrategy/

Russian Federation state program "Energy saving and energy efficiency improvement to the period up to 2020 year": http://www.rg.ru/2011/01/25/energosberejenie-site-dok.html

Russian Federation Presidential Decree from the $4^{\text {th }}$ of June 2008 year N. N 889 "About some measures on energy and ecological efficiency improvement of Russian economy": http://graph.document.kremlin.ru/page.aspx?963479

Kuleshov, D., Viljainen, S., Annala, S., Gore, O., Russian electricity sector reform: Challenges to retail competition. Utilities Policy (23), 2012. pp. 40-49. 
Erdogdu, E. The impact of power market reforms on electricity price-cost margins and cross-subsidy levels: A cross country panel data analysis // Energy Policy (39), 2011. pp.1080-1092.

Sadriev A.R., Pratchenko O.V. Idea management in the system of innovative management // Mediterranean Journal of Social Sciences 5 (12), 2014, pp. 155-158.

Kirshin I.A., Gareev B.R. Theory of constraints in value based cost management // World Applied Sciences Journal (Economics, Management and Finance) 27, 2013, pp. 102-106.

Nepal, R., Jamasb, T. Restructuring the power sector in transition: Do institutions matter? // Energy Economics (34), 2012. pp. 16751682.

Melnik A.N., Ermolaev K.A., Antonova N.V. Stages in formalizing energy conservation and efficiency management in industrial enterprises. // Mediterranean Journal of Social Sciences 5 (12), 2014, pp. 173-176.

Varlamova J.A., Larionova N.I. Economic behavior of households: cross-country comparison // Life Science Journal, 2014; 11(6s), pp. 409-413. 